\title{
Study of drying kinetics and quality attributes of fermented corn grains as affected by drying temperatures and velocities
}

\begin{abstract}
Corn grains were fermented for three days and later drained and dried at $60^{\circ} \mathrm{C}, 65^{\circ} \mathrm{C}$ and $70^{\circ} \mathrm{C}$ and air velocity of $1.37,1.82$ and $2.32 \mathrm{~m} / \mathrm{s}$ in a convective hot air dryer. Kinetics of drying was investigated using Fick's second law. The dried samples were milled and analyzed for proximate (moisture, protein, fat, ash, fibre and carbohydrtes) and physicochemical properties (water absorption capacity, least gelation, swelling capacity, loose and packed bulk density). Non-linear regression analysis was used for the modelling kinetics and analysis of variance. Drying pattern was observed to be in the falling rate period and the coefficient of determination $R^{2}$ ranged from 0.861 to 0.999, Root Mean Square Error (RMSE) ranged from 0.0310 to 0.3808 , Mean Bias Error (MBE) ranged from 0.000296 to 0.1114 and reduced chi square $x^{2}$ ranged from 0.000815 to 0.2610 . Proximate results were as follows: moisture (10.05-11.36\%), protein $(8.23-8.70 \%)$, fat (3.23-3.56\%), ash (1.25$1.33 \%)$, fibre $(2.10-2.31 \%)$ and carbohydrate $(74.23-74.80 \%)$. Physico-chemical results were as follows: water absorption capacity $\left(1.03-1.37 \mathrm{~cm}^{3} / \mathrm{g}\right)$, least gelation capacity $(3.47-$ $3.52 \%)$, swelling capacity (1.10-1.36 g water/g sample), loose bulk density (0.52-0.53 g/ $\left.\mathrm{cm}^{3}\right)$ and packed bulk density $\left(0.75-0.79 \mathrm{~g} / \mathrm{cm}^{3}\right)$. It can be concluded that at air velocity of $1.37 \mathrm{~m} / \mathrm{s}$, Logarithm model best described the drying behaviour of the samples while at air velocity of 1.87 and $2.32 \mathrm{~m} / \mathrm{s}$, Midilli models had the best fit describing the drying characteristics of the samples. Increase in temperature and air velocity decreased the values of moisture and fat content but increased water absorption capacity and swelling capacity.
\end{abstract}

Keywords: fermented corn, hot air drying, mathematical modeling, quality attribute and laboratory tunnel dryer
Volume 8 Issue 2 - 2018

\author{
AS Ajala, Abubakar MA \\ Food Science and Engineering Department, Ladoke Akintola \\ University of Technology, Ogbomoso, Nigeria
}

Correspondence: AS Ajala, Food Science and Engineering Department, Ladoke Akintola University of Technology, Ogbomoso, Nigeria, Tel +2348064l85475, Email ajlad2000@yahoo.com

Received: February 09, 2018| Published: April 05, 2018
Abbreviations: $\mathrm{D}_{\text {eff, }}$ moisture diffusivity $\left(\mathrm{m}^{2} / \mathrm{s}\right)$; L, half of the thickness of the sample $\left(\mathrm{m}^{2}\right) ; \mathrm{M}_{0}$, initial moisture content of the sample (g water/g solid); $\mathrm{M}_{\mathrm{i}}$, instantaneous moisture content of the sample (g water/g solid); $\mathrm{M}_{\mathrm{e}}$, equilibrium moisture content of the sample (g water/g solid); MBE, mean bias error; MR, moisture ratio; $\mathrm{MR}_{\text {exp }}$, experimental moisture ratio; $\mathrm{MR}_{\text {pre }}$, predicted moisture ratio; $\mathrm{n}$, Drying constant in the model; N, number of observation; RMSE, root mean square error; $\mathrm{R}^{2}$, coefficient of determination; $\mathrm{t}$, drying time (hr); $\chi^{2}$, reduced chi square; $\mathrm{z}$, number of constant in the models

\section{Introduction}

Corn or maize constitutes a staple food in many regions of the world. In 2011, the United State produced 274 million metric tons followed by China with an estimate of 208 million metric tons. Other producing countries include Brazil, Mexico, Argentina, India, France, Canada and South Africa with estimates of 71, 22, 21, 21, 16, 12 and 12 million metric tons, respectively, ${ }^{1}$ Corn grains find its application in different cultures and based on the level technology accrued, nutritional knowledge, societal status and processing factors. In general, maize finds usefulness in domestic food consumption and industrial raw materials. Others include pharmaceutical, biofuels and ornamental uses. Specifically, it can be consumed in the unripe state when the kernels are fully grown but still soft simply by boiling or roasting the whole ears and eating the kernels right off the cob. ${ }^{2,3}$ It is a major source of starch and cooking oil (corn oil) and of corn gluten. According to Jadhav et al. ${ }^{4}$ maize starch can be hydrolyzed and enzymatically treated to form syrups, particularly high fructose corn syrup which can also be fermented and distilled to produce grain alcohol. Fermented corn grains are widely used as weaning food for infant and as dietary staples for adults..$^{5-7}$ One of the African foods is 'ogi'. This is a porridge prepared from fermented maize, sorghum or millet in West Africa that forms a staple food of that region and serves as a weaning food for infants. 'Mahewu' is another staple food popular among native South African and it is traditionally prepared by adding one part of maize meal to 9 parts of boiling water. The suspension is cooked for 10 minutes, allowed to cool and then transferred to a container where it is left for fermentation. At this stage, wheat flour about $5 \%$ of the maize meal is added to serve as a source of inoculum. Other African products are 'eko agidi', 'kenkey', 'bogobe', 'injera', 'kisira' and local alcohol.

One of the ways to preserve corn is by drying and transformation to flour; it can be preserved in this form and can have shelf life of more than 6 months. Corn flour is used as a replacement for wheat flour to make cornbread and other baked products. ${ }^{8}$ Generally, treatments such as steeping, milling, sieving and drying are involved in preparation of these fermented foods. ${ }^{6}$ Mostly in Africa, after harvesting, drying of corn is done by spreading the product under sun for moisture removal; although cheaper but the products are of low quality due to environmental contamination such as dust and insects. In view of this fact, drying of corn using mechanical dryer is a better option over sun drying considering the economic importance of the product to Africans. As a result of this, fermented corn grains 
were dried in a tunnel dryer with two objectives in mind. The first objectives were to investigate drying characteristics of fermented corn grains by using mathematical modeling of thin layer drying. This was done to analyze the moisture diffusion coefficients which play important role in moisture transport during drying since mathematical modeling using thin layer drying models has been applied in drying of fruits, vegetables, seafood and other agricultural products. ${ }^{9,10}$ The second objective was to study the effect of combinations of drying parameters (temperatures and air velocity) on the nutritional quality attributes of fermented corn grains flour

\section{Material and methods}

\section{Materials}

Dried corn grains procured from a local market were used for the experiment. They were sorted and winnowed so as to eliminate all form of dirt and physical contaminants that were likely to be present in the samples. After that, the sorted corn grains were soaked in potable water for three days to effect fermentation. After fermentation, they were drained, dried and packaged for chemical analysis. The reagents used to determine the nutritional properties were of analytical grade.

\section{Methods}

\section{Drying experiment}

The drying experiment was performed in a tunnel dryer built in the Department of Food Science and Engineering, Ladoke Akintola University of Technology, Ogbomoso Nigeria. The dryer was operated at air temperature of 60,65 and $70^{\circ} \mathrm{C}$ at constant air velocity of 1.37 , 1.82 and $2.32 \mathrm{~m} / \mathrm{s}$. The dryer was installed in an environmental condition of $51 \%$ relative humidity and $29^{\circ} \mathrm{C}$ ambient temperature. The temperature and the air velocity in the dryer were at steady state before samples were introduced into the dryer. Corn grains with rectangular slab-like structure were selected for the experiments. The grain had average dimensions of $8 \times 5 \times 3 \mathrm{~mm}$ measured with Vernier caliper. The samples were placed in the dryer and removed manually every 1 hour to determine weight loss of the sample. The drying experiment was stopped when three consecutive sample weights remained constant. The samples were removed from the dryer, milled in a disc attrition machine, sieved and packaged in air tight plastic bags for further analysis.

\section{Mathematical model}

To understand the suitable model for the drying characteristics of the samples, the experimental data were fitted in four models described in Table 1.

Table I Mathematical drying models

\begin{tabular}{lll}
\hline Models & Equation & References \\
\hline Henderson and Pabis & $M R=a \exp (-k \mathrm{t})$ & Aregesola et al. ${ }^{16}$ \\
Newton & $M R=\exp (-k \mathrm{t})$ & Kingly et al. ${ }^{17}$ \\
Midilli et al. ${ }^{18}$ & $M R=a \exp (-k t n)+b t$ & Midilli et al. ${ }^{18}$ \\
Logarithms & $M R=a \exp (-k t)+c$ & $\begin{array}{l}\text { Togrul and } \\
\text { Pehlivan }\end{array}$ \\
\hline
\end{tabular}

These models show relationship between moisture ratio and drying time. Moisture ratio (MR) during the thin layer drying was obtained using equation 1

$$
M R=\frac{M_{i}-M_{e}}{M_{o}-M_{e}}
$$

However, due to continuous fluctuation of relative humidity of the drying air in the dryer, equation 1 is simplified in equation $2^{11,1}$

$$
M R=\frac{M_{i}}{M_{o}}
$$

\section{Estimation of the drying models constants}

The drying model constants were estimated using a non-linear regression analysis. The analysis was performed using Statistical Package for Social Scientist (SPSS 15.0 version) software. The reliability of the models was verified using statistical criteria such as coefficient if determination $R^{2}$, reduced chi-square $x^{2}$, root mean square error (RMSE) and mean bias error (MBE). A good fit is said to occur between experimental and predicted values of a model when $R^{2}$ is high and $x^{2}$, RMSE and MBE are lower. ${ }^{13,14}$ The statistical criteria to test the reliability of the models are as follows:

$$
\begin{aligned}
& X^{2}=\frac{\sum_{i-1}^{n}\left(M R_{(\exp , i)}-M R_{(\text {pred }, i)}\right)^{2}}{N-z} \\
& M B E=\frac{1}{N} \sum_{i=1}^{n}\left(M R_{(\text {pred }, i)}-M R_{(\exp , i)}\right) \\
& R^{2}
\end{aligned}
$$

\section{Determination of moisture diffusivity}

Fick's equation can be simplified to describe the drying characteristics of fermented corn grains. The simplified equation was used to determine the effective moisture diffusion from the samples during drying. The equation according to Srikiatden \& Regbesola et al. ${ }^{15,16-19}$ is represented thus:

$$
M R=\frac{M-M_{0}}{M_{0}-M_{e}}=\frac{8}{\pi^{2}} \sum_{n=0}^{n=1} \frac{1}{(2 n-1)^{2}} \exp \frac{-(2 n-1)^{2} \pi^{2} D_{e f f} t}{4 l^{2}}
$$

The effective moisture diffusivity $D_{\text {eff }}$ was calculated from the slope of plot of $\ln$ MR against drying time ${ }^{\text {eff }}(\mathrm{t})$ according to Doymas, ${ }^{20}$ is represented in equation 7

$$
K=\frac{D_{e f f} t}{4 l^{2}}
$$

Where $k$ is the slope.

\section{Chemical analysis of the samples}

The dried and fermented corm grain flours were subjected to the following analyses in order to determine its nutritional composition

\section{Proximate and chemical composition analyses}

Moisture content, ash, protein, fat and carbohydrate content. Also, solubility, swelling capacity, least gelation concentration, water absorption capacity and bulk density were analysed using AOAC methods. ${ }^{21}$ 


\section{Statistical analysis}

All determination of proximate composition and functional properties analysis as reported in this study were carried out in triplicates. In each case, a mean value was calculated and analysis of variance (ANOVA) was also performed and separation of the mean values was done by Duncan's multiple range test at $p<0.05$ using statistical package for social scientist (SPSS) software, version 15.0.

\section{Results and discussion}

\section{Effect of temperature on moisture content and} moisture ratio

The pattern of moisture loss in the sample is as shown in Figures $1-3$. From the graph, it was observed that the samples exhibited a falling rate pattern. This is true because most agricultural products often exhibit falling rate period as reported by Ajala \& Ajala, ${ }^{22}$ Velic et al., ${ }^{23}$ Karel \& Lund, ${ }^{24}$ Ramaswamy \& Marcotte. ${ }^{25}$ During the falling rate period, drying occurred which mainly controlled by internal factor of diffusion mechanism in the grain as reported by Ramaswamy \& Marcotte,,$^{25}$ unlike constant rate period which could be controlled by external condition such as temperature, air humidity and air velocity. At this stage, there was no resistance to mass transfer. ${ }^{11,23}$ The effect of

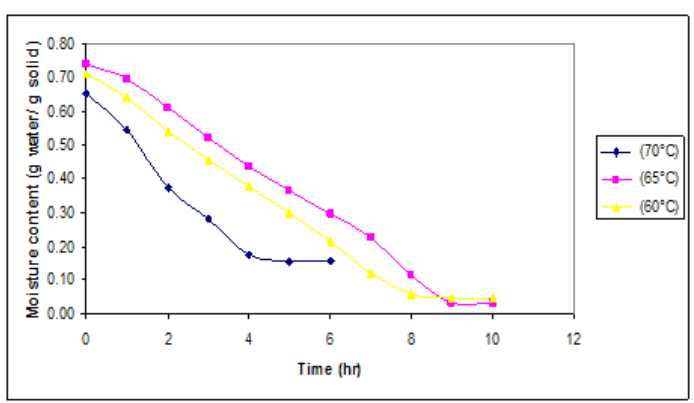

Figure I Graph showing moisture content against time when $v=1.37 \mathrm{~m} / \mathrm{s}$.

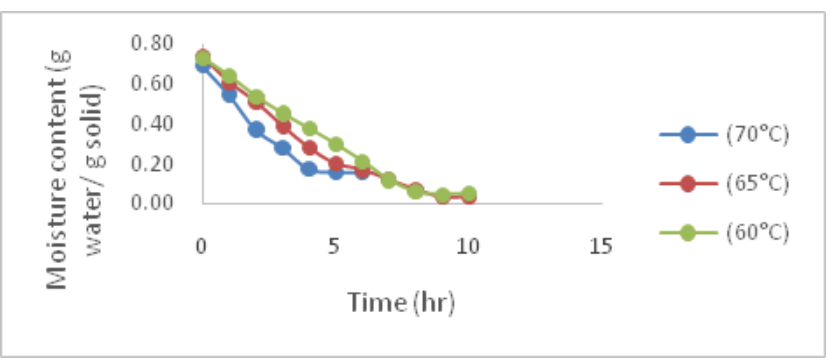

Figure 2 Graph showing moisture content against time when $v=1.87 \mathrm{~m} / \mathrm{s}$.

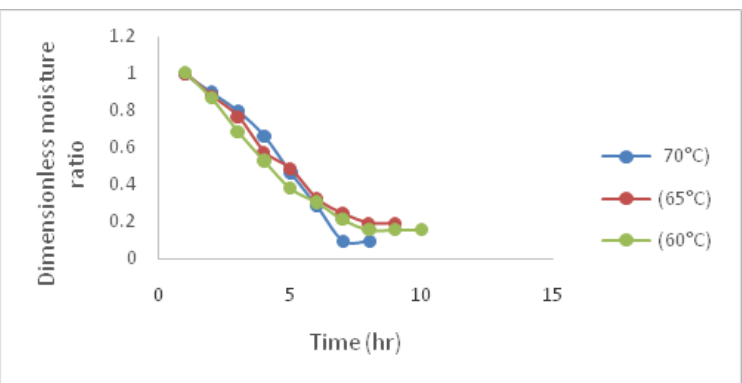

Figure 5 Graph showing moisture ratio against time when $v=1.87 \mathrm{~m} / \mathrm{s}$. temperatures on the drying characteristics of the sample shows that in Figure 1, it took 4 hours for moisture loss from 0.69 (g water/g solid) to 0.17 (g water/ $\mathrm{g}$ solid) at drying temperature of $70^{\circ} \mathrm{C}$. Also, it took 4 hours to bring moisture content from 0.73 to $0.28 \mathrm{~g}$ water/ $\mathrm{g}$ solid at $65^{\circ} \mathrm{C}$ while it took the same hour to bring the moisture content of the sample from 0.73 to $0.38 \mathrm{~g}$ water/ $\mathrm{g}$ solid at $60^{\circ} \mathrm{C}$. The same trend of temperature effect was observed as observed in (Figures 2) \& (Figures $3)$. It was deduced from this data that higher temperatures induced higher moisture removal from the grains. The greater the temperature difference between the drying air and the food, the greater the heat transfer to the food and faster the moisture removal from the grains. This observation was earlier reported by Ajala \& Ajala, ${ }^{13}$ Bellagha et al. $^{26}$

The pattern of dimensionless moisture ratio against drying time is demonstrated in Figures 4, Figures 5 \& Figures 6 . The drying rate was faster at $70^{\circ} \mathrm{C}$ than $65^{\circ} \mathrm{C}$ and $60^{\circ} \mathrm{C}$; this is because moisture removal was faster at $70^{\circ} \mathrm{C}$ than other two temperatures. This same observation was reported in literature. ${ }^{27,28}$ In the same vein, the moisture ratio gradient caused by temperature difference between the solid and drying medium at $60^{\circ} \mathrm{C}$ was lower than $65^{\circ} \mathrm{C}$ and the moisture gradient at $70^{\circ} \mathrm{C}$ was the steepest. This could explain further the reason for moisture removal at $70^{\circ} \mathrm{C}$ was faster than lower temperatures.

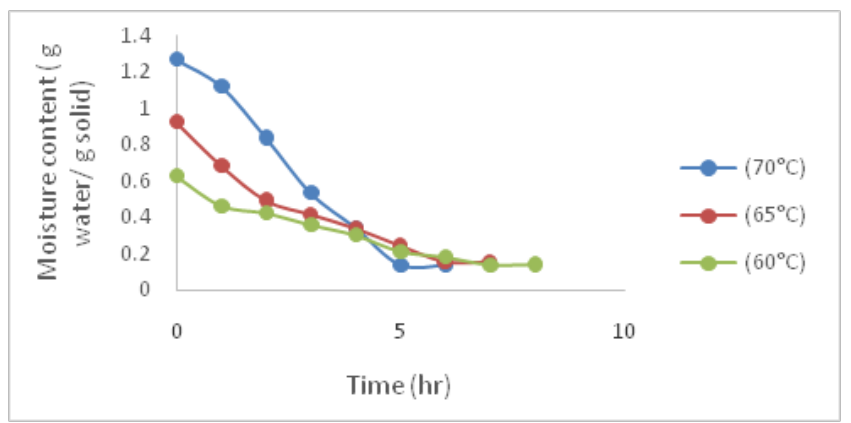

Figure 3 Graph showing moisture content against time when $v=2.32 \mathrm{~m} / \mathrm{s}$.

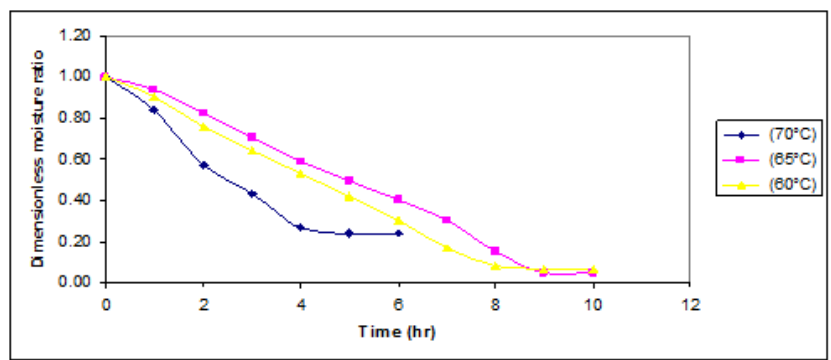

Figure 4 Graph showing moisture ratio against time when v= $1.37 \mathrm{~m} / \mathrm{s}$.

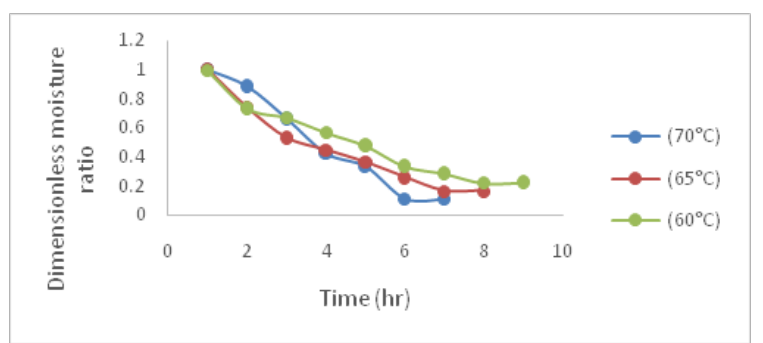

Figure 6 Graph showing moisture ratio against time when $v=2.32 \mathrm{~m} / \mathrm{s}$. 


\section{Statistical results}

The results of statistical criteria for the models were as observed in Table 2-4. These were determined from fitting the experimental moisture ratio against drying time to evaluate the goodness of fit. In Table 2, coefficient of determination $R^{2}$ was greater than 0.90 except Midilli at $70^{\circ} \mathrm{C}$. The values of chi square ranged from 0.002317 to $0.05815,0.002181$ to $0.009818,0.000815$ to 0.018972 and 0.001826 to 0.003961 for Henderson and Pabis, Newton, Midilli and Logarithms models, respectively. The lowest values for MBE was

Table 2 Values of statistical parameters when $v=1.37 \mathrm{~m} / \mathrm{s}$

\begin{tabular}{|c|c|c|c|c|c|}
\hline Model & Temp & $\mathrm{a}$ & $x^{2}$ & MBE & RMSE \\
\hline \multirow[t]{3}{*}{$\begin{array}{l}\text { Henderson } \\
\text { and Pabis }\end{array}$} & 70 & 0.969 & 0.002317 & 0.000296 & 0.039301 \\
\hline & 65 & 0.948 & 0.05815 & 0.00194 & 0.068208 \\
\hline & 60 & 0.955 & 0.005288 & 0.000874 & 0.065042 \\
\hline \multirow[t]{3}{*}{ Newton } & 70 & 0.976 & 0.002181 & 0.007854 & 0.043238 \\
\hline & 65 & 0.917 & 0.009818 & 0.01285 & 0.094473 \\
\hline & 60 & 0.936 & 0.007875 & 0.00846 & 0.084613 \\
\hline \multirow[t]{3}{*}{ Midilli' $^{18}$} & 70 & 0.861 & 0.018972 & 0.00126 & 0.079523 \\
\hline & 65 & 0.992 & 0.001157 & 0.005335 & 0.026348 \\
\hline & 60 & 0.996 & 0.000815 & 0.00451 & $0.02277 \mid$ \\
\hline \multirow[t]{3}{*}{ Logarithms } & 70 & 0.979 & 0.003961 & 0.01182 & 0.0445 \\
\hline & 65 & 0.993 & 0.002178 & 0.00727 & 0.039802 \\
\hline & 60 & 0.997 & 0.001826 & 0.00791 & 0.03644 \\
\hline
\end{tabular}

Table 4 Values of statistical parameters when $v=2.32 \mathrm{~m} / \mathrm{s}$

\begin{tabular}{llllll}
\hline Model & Temp & $R^{2}$ & $x^{2}$ & MBE & RMSE \\
\hline $\begin{array}{l}\text { Henderson } \\
\text { and Pabis }\end{array}$ & 70 & 0.948 & 0.0147 & 0.0125 & 0.107 \\
& 65 & 0.992 & 0.016 & 0.0819 & 0.1116 \\
& 60 & 0.986 & 0.0014 & 0.0022 & 0.0331 \\
& 70 & 0.935 & 0.0069 & 0.0105 & 0.0787 \\
& 65 & 0.991 & 0.0131 & 0.0809 & 0.1078 \\
& 60 & 0.981 & 0.0011 & 0.0041 & 0.0317 \\
& 70 & 0.991 & 0.023 & 0.0145 & 0.1131 \\
& 65 & 0.988 & 0.261 & 0.1818 & 0.3808 \\
& 60 & 0.989 & 0.1982 & 0.1008 & 0.3318 \\
& 70 & 0.979 & 0.0186 & 0.0165 & 0.1116 \\
& 65 & 0.993 & 0.019 & 0.0819 & 0.1125 \\
& 60 & 0.986 & 0.0014 & 0.0022 & 0.031 \\
\hline
\end{tabular}

0.000296 in Henderson and Pabis Model while the highest value was 0.01285 in Newton model. The lowest RMSE value was 0.022771 found in Midilli model while 0.094473 in Newton model was the highest value. In Table 3, the values of $R^{2}$ were greater than 0.90 except Newton at $70^{\circ} \mathrm{C}$. The values of mean bias error (MBE) ranged from 0.0022 to $0.0819,0.0145$ to $0.0809,0.0145$ to 0.1818 and 0.0165 to 0.0819 for Henderson and Pabis, Newton, Midilli and Logarithms models, respectively. In Table 4, the values of $R^{2}$ were greater than 0.93 in all the models.

Table 3 Values of statistical parameters when $v=1.82 \mathrm{~m} / \mathrm{s}$

\begin{tabular}{|c|c|c|c|c|c|}
\hline Model & Temp & $R^{2}$ & $x^{2}$ & MBE & RMSE \\
\hline \multirow[t]{3}{*}{$\begin{array}{l}\text { Henderson } \\
\text { and Pabis }\end{array}$} & 70 & 0.904 & 0.0183 & 0.0395 & 0.1132 \\
\hline & 65 & 0.975 & 0.0055 & 0.0182 & 0.0625 \\
\hline & 60 & 0.988 & 0.0015 & 0.0014 & 0.0324 \\
\hline \multirow[t]{3}{*}{ Newton } & 70 & 0.883 & 0.0195 & 0.0265 & 0.1249 \\
\hline & 65 & 0.967 & 0.006 & 0.0102 & 0.0695 \\
\hline & 60 & 0.983 & 0.0015 & 0.0045 & 0.0356 \\
\hline \multirow[t]{3}{*}{ Midilli ${ }^{18}$} & 70 & 0.997 & 0.2053 & 0.1114 & 0.3204 \\
\hline & 65 & 0.963 & 0.2055 & 0.1017 & 0.3206 \\
\hline & 60 & 0.999 & 0.0052 & 0.0156 & 0.0509 \\
\hline \multirow[t]{3}{*}{ Logarithms } & 70 & 0.979 & 0.0143 & 0.0325 & 0.0927 \\
\hline & 65 & 0.985 & 0.0029 & 0.0062 & 0.0419 \\
\hline & 60 & 0.989 & 0.0017 & 0.0024 & 0.0319 \\
\hline
\end{tabular}

The values of root mean square error (RMSE) ranged from 0.0331 to $0.1116,0.0317$ to $0.1078,0.1131$ to 0.3808 and 0.0310 to 0.1125 for Henderson and Pabis, Newton, Midilli and Logarithms models, respectively. The goodness of fit for a model is when $\mathrm{R}^{2}$ is high and chi square, RMSE, MBE values are low as earlier stated. After analyzing the models, it was found that at drying velocity of $1.37 \mathrm{~m} / \mathrm{s}$, Logarithms model has the highest average value of $\mathrm{R}^{2}$ and lowest value of chi square which suggested that Logarithms model best described the experimental thin layer drying of the samples. However, at the air drying velocity of 1.87 and $2.32 \mathrm{~m} / \mathrm{s}$, the Midilli model has the highest average value of $R^{2}$ and low value of mean bias error and root mean square error respectively, which suggested that Midilli model best described the experimental thin layer drying of the samples.

This suggests that temperatures affect modelling process and drying rate pattern of agricultural product. But, the effect of the velocity on the drying rate was not significantly observed at air velocity of 1.87 and $2.32 \mathrm{~m} / \mathrm{s}$ any more than $1.37 \mathrm{~m} / \mathrm{s}$ for the corn grains in this study. This is because, it took $6 \mathrm{hrs}$ for drying the product at $70^{\circ} \mathrm{C}$ when $\mathrm{v}=1.37 \mathrm{~m} / \mathrm{s}$ as shown in Figure 1, likewise it also took the 6 to dry the product at $70^{\circ} \mathrm{C}$ when $v=1.87$ but it took 7 hrs to dry the corn samples at $70^{\circ} \mathrm{C}$ when $\mathrm{v}=2.32 \mathrm{~m} / \mathrm{s}$. Therefore, this implies that higher air 
velocity could induce higher drying rate in samples but occasionally a stage may be reached when increase in the air velocity has no more effect. This was earlier observed by Ajala. Because of this occasional occurrence, ASTM ${ }^{29}$ recommends maximum useful air speed of $3 \mathrm{~m} / \mathrm{s}$ flowing parallel to the surface. This is based on recommended speed for a wet bulb thermometer on a sling psychrometer regardless of the humidity of the air.

Table 5 Values for model constants when $v=1.37 \mathrm{~m} / \mathrm{s}$

\begin{tabular}{|c|c|c|c|c|c|c|}
\hline Model & Temp & $\mathbf{N}$ & $\mathbf{a}$ & $\mathbf{k}$ & B & C \\
\hline \multirow[t]{3}{*}{$\begin{array}{l}\text { Henderson } \\
\text { and Pabis }\end{array}$} & 70 & & 1.115 & -0.313 & & \\
\hline & 65 & & 1.214 & -0.266 & & \\
\hline & 60 & & 1.213 & -0.252 & & \\
\hline \multirow[t]{3}{*}{ Newton } & 70 & & & 0.275 & & \\
\hline & 65 & & & 0.168 & & \\
\hline & 60 & & & 0.203 & & \\
\hline \multirow[t]{3}{*}{ Midilli'18 } & 70 & -6. IE7 & 0.852 & 0.009 & -0.118 & \\
\hline & 65 & -0.089 & -0.049 & -3.06 & -0.021 & \\
\hline & 60 & 1.464 & 0.988 & 0.075 & -0.011 & \\
\hline \multirow[t]{3}{*}{ Logarithms } & 70 & & 0.998 & -0.308 & & 0.039 \\
\hline & 65 & & 5.298 & -0.021 & & -4.269 \\
\hline & 60 & & 1.949 & -0.077 & & -0.92 \\
\hline
\end{tabular}

Table 7 Values for model constants when $\mathrm{v}=2.32 \mathrm{~m} / \mathrm{s}$

\begin{tabular}{lllllll}
\hline Model & Temp & $\mathrm{n}$ & $\mathrm{a}$ & $\mathrm{k}$ & $\mathrm{b}$ & $\mathrm{c}$ \\
\hline \multirow{2}{*}{ Henderson } & 70 & & 1.084 & 0.313 & & \\
and Pabis & 65 & & 0.982 & 0.269 & & \\
& 60 & & 0.969 & 0.195 & & \\
& 70 & & & 0.287 & & \\
Newton & 65 & & & 0.275 & & \\
& 60 & & & 0.205 & & \\
& 70 & 1.674 & 1.003 & 0.134 & 0.004 & \\
Midilli'8 & 65 & -0.193 & 0.153 & -1.635 & -0.047 & \\
& 60 & -0.009 & 0.254 & -1.193 & -0.088 & \\
& 70 & & 1.958 & 0.116 & & -0.917 \\
& 65 & & 0.944 & 0.299 & & 0.046 \\
& 60 & & 0.999 & 0.183 & & -0.034 \\
\hline
\end{tabular}

\section{Effective diffusivity}

Table 8 presents the values for effective moisture diffusivity of the fermented corn grains. It was shown that the effective diffusivity is temperature and velocity dependent. At air velocity of $1.37 \mathrm{~m} / \mathrm{s}$, the effective moisture diffusivity values were $2.78 \times 10^{-11}, 2.95 \times 10^{-11}$ and $3.06 \times 10^{-11} \mathrm{~m}^{2} / \mathrm{s}$ for 60,65 and $70^{\circ} \mathrm{C}$, respectively. In the same trend, at air velocity of $1.82 \mathrm{~m} / \mathrm{s}$, the effective moisture diffusivity increased to $2.84 \times 10^{-11}, 3.24 \times 10^{-11}$ and $4.05 \times 10^{-11} \mathrm{~m}^{2} / \mathrm{s}$ for 60 , 65 and $70^{\circ} \mathrm{C}$, respectively. On the contrary, the trend of effective moisture diffusivity decreased at air velocity of $2.32 \mathrm{~m}^{2} / \mathrm{s}$ with values of $2.03 \times 10^{-11}, 2.84 \times 10^{-11}$ and $3.24 \times 10^{-11} \mathrm{~m}^{2} / \mathrm{s}$ for 60,65 and $70^{\circ} \mathrm{C}$,
The values of models constants are as demonstrated in Table 5-7. The Hernderson and Pabis model has values of 1.115, 1.214 and 1.213 for constant ' $a$ ' as shown in Table 5; details for other constants for all models are as recorded in Table 5-7. It was observed that model constants vary with different air temperatures and velocities. The apparent differences in the constants show that drying parameters could have significant effect on modeling the drying process.

Table 6 Values for model constants when $v=1.82 \mathrm{~m} / \mathrm{s}$

\begin{tabular}{|c|c|c|c|c|c|c|}
\hline Model & Temp & $\mathbf{n}$ & $\mathbf{a}$ & $\mathbf{k}$ & b & c \\
\hline \multirow[t]{3}{*}{$\begin{array}{l}\text { Henderson } \\
\text { and Pabis }\end{array}$} & 70 & & 1.107 & 0.24 & & \\
\hline & 65 & & I & 0.662 & & \\
\hline & 60 & & 1.053 & 0.24 & & \\
\hline \multirow[t]{3}{*}{ Newton } & 70 & & & 0.214 & & \\
\hline & 65 & & & 0.201 & & \\
\hline & 60 & & & 0.217 & & \\
\hline \multirow[t]{3}{*}{ Midilli' ${ }^{18}$} & 70 & -30 & 1.098 & 0.041 & -0.154 & \\
\hline & 65 & 2. $12 \mathrm{E} 8$ & 0.945 & 0.017 & -0.105 & \\
\hline & 60 & 1.381 & 1.009 & 0.157 & 0.011 & \\
\hline \multirow[t]{3}{*}{ Logarithms } & 70 & & II 2.835 & 0.001 & & -111.8 \\
\hline & 65 & & 1.359 & -0.966 & & -0.325 \\
\hline & 60 & & 1.073 & 0.227 & & -0.026 \\
\hline
\end{tabular}

Table 8 Effective moisture diffusivities for fermented corn grains

\begin{tabular}{lll}
\hline $\begin{array}{l}\text { Air } \\
\text { velocity } \\
(\mathrm{m} / \mathrm{s})\end{array}$ & $\begin{array}{l}\text { Air temperature } \\
\left({ }^{\circ} \mathrm{C}\right)\end{array}$ & $\begin{array}{l}\text { Effective moisture diffusivity } \\
\left(\mathrm{m}^{2} / \mathrm{s}\right)\end{array}$ \\
\hline $\mathrm{I} .37$ & 60 & 2.78 \\
$\mathrm{I} .37$ & 65 & 2.95 \\
$\mathrm{I} .37$ & 70 & 3.06 \\
$\mathrm{I} .82$ & 60 & 2.84 \\
$\mathrm{I} .82$ & 65 & 3.24 \\
$\mathrm{I} .82$ & 70 & 4.05 \\
2.32 & 60 & 2.03 \\
2.32 & 65 & 2.84 \\
2.32 & 70 & 3.24 \\
\hline
\end{tabular}

respectively. In summary, effective moisture diffusivity was directly influenced by both temperature and air velocity but at a certain stage, further increment in air velocity could reduce the effective moisture diffusivity as earlier stated. This observation is in line with other authors. ${ }^{11,23,30-33}$ The values of effective moisture diffusivity obtained are within the range of food product $\left(10^{-11}\right.$ to $\left.10^{-6} \mathrm{~m}^{2} / \mathrm{s}\right)$ as reported by Doymaz. ${ }^{34}$ However, the value of moisture diffusivity was less than that of vegetables. For instance, tomato dried at $75^{\circ} \mathrm{C}$ has $D_{\text {eff }}$ of $12.27 \times 10^{-9} \mathrm{~m}^{2} / \mathrm{s}$ as reported by Akanbi et al. ${ }^{35}$ The lower values in corn grain when compared to vegetables were due to the lower moisture content of the grain, internal structure and thick outer coat of the corn. 
Table 9 Evaluation of proximate composition of dry fermented corn grains

\begin{tabular}{|c|c|c|c|c|c|c|c|}
\hline $\mathrm{T}\left({ }^{\circ} \mathrm{C}\right)$ & $\mathbf{V}(\mathrm{m} / \mathrm{s})$ & Moisture (\%) & Protein (\%) & Fat (\%) & Ash (\%) & Fibre (\%) & Carbohydrate (\%) \\
\hline 60 & I.37 & $11.36 \pm 0.92^{c}$ & $8.43 \pm 0.76^{a}$ & $3.53 \pm 0.47^{c}$ & $\mathrm{I} .33 \pm 0.0 \mathrm{I}^{\mathrm{a}}$ & $2.10 \pm 0.02^{\mathrm{a}}$ & $74.53 \pm 3.45^{\mathrm{a}}$ \\
\hline 60 & 1.82 & $1 \mathrm{I} .33 \pm 0.87^{\mathrm{c}}$ & $8.30 \pm 1.03^{a}$ & $3.56 \pm 0.65^{c}$ & $|.3| \pm 0.0 I^{a}$ & $2.10 \pm 0.03^{a}$ & $74.86 \pm 2.89^{a}$ \\
\hline 60 & 2.32 & $11.33 \pm 1.09^{c}$ & $8.23 \pm 0.88^{a}$ & $3.54 \pm 0.12^{c}$ & $1.26 \pm 0.02^{\mathrm{a}}$ & $2.10 \pm 0.02^{\mathrm{a}}$ & $74.80 \pm 4.87^{a}$ \\
\hline 65 & 1.37 & $10.84 \pm 0.53^{\mathrm{b}}$ & $8.40 \pm 0.54^{\mathrm{ab}}$ & $3.43 \pm 0.2 \mathrm{I}^{\mathrm{b}}$ & $\mathrm{I} .30 \pm 0.0 \mathrm{I}^{\mathrm{a}}$ & $2.10 \pm 0.01^{\mathrm{a}}$ & $74.53 \pm 3.26^{\mathrm{a}}$ \\
\hline 65 & 1.82 & $10.81 \pm 1.02^{b}$ & $8.30 \pm 0.49^{\mathrm{ab}}$ & $3.33 \pm 0.22^{\mathrm{b}}$ & $1.26 \pm 0.02^{\mathrm{a}}$ & $2.10 \pm 0.01^{a}$ & $74.70 \pm 4.2 \mathrm{I}^{\mathrm{a}}$ \\
\hline 65 & 2.32 & $10.79 \pm 0.99^{b}$ & $8.53 \pm 0.76^{\mathrm{ab}}$ & $3.40 \pm 0.34^{b}$ & $1.30 \pm 0.02^{\mathrm{a}}$ & $2.10 \pm 0.03^{a}$ & $74.26 \pm 2.43^{\mathrm{a}}$ \\
\hline 70 & 1.37 & $10.30 \pm 0.65^{\mathrm{a}}$ & $8.36 \pm 0.49^{b}$ & $3.30 \pm 0.55^{\mathrm{a}}$ & $\mathrm{I} .30 \pm 0.0 \mathrm{I}^{\mathrm{a}}$ & $2.31 \pm 0.04^{a}$ & $74.53 \pm 3.22^{\mathrm{a}}$ \\
\hline 70 & 1.82 & $10.20 \pm 0.78^{\mathrm{a}}$ & $8.30 \pm 0.47^{b}$ & $3.26 \pm 0.57^{\mathrm{a}}$ & $1.25 \pm 0.03^{\mathrm{a}}$ & $2.13 \pm 0.03^{a}$ & $74.66 \pm 3.12^{\mathrm{a}}$ \\
\hline 70 & 2.32 & $10.05 \pm 0.84^{\mathrm{a}}$ & $8.70 \pm 0.89^{b}$ & $3.23 \pm 0.44^{\mathrm{a}}$ & $1.33 \pm 0.04^{a}$ & $2.13 \pm 0.02^{\mathrm{a}}$ & $74.23 \pm 2.99^{a}$ \\
\hline
\end{tabular}

T, drying temperature $\left({ }^{\circ} \mathrm{C}\right) ; \mathrm{V}$, air velocity $(\mathrm{m} / \mathrm{s})$, a, b, c, $\mathrm{k}$, Drying constant in the model

Table 10 Evaluation of physico-chemical compositions of dry fermented corn grains

\begin{tabular}{|c|c|c|c|c|c|c|}
\hline $\mathrm{T}\left({ }^{\circ} \mathrm{C}\right)$ & $\begin{array}{l}\text { Air velocity } \\
(\mathrm{m} / \mathrm{s})\end{array}$ & $\begin{array}{l}\text { Water absorption } \\
\text { capacity }\left(\mathrm{cm}^{3} / \mathrm{g}\right)\end{array}$ & $\begin{array}{l}\text { Least gelation } \\
\text { capacity }(\%)\end{array}$ & $\begin{array}{l}\text { Swelling capacity (g } \\
\text { water/g sample) }\end{array}$ & $\begin{array}{l}\text { Loose bulk } \\
\text { density (g/ } \\
\left.\mathrm{cm}^{3}\right)\end{array}$ & $\begin{array}{l}\text { Packed bulk } \\
\text { density }\left(\mathrm{g} / \mathrm{cm}^{3}\right)\end{array}$ \\
\hline 60 & 1.37 & $1.03 \pm 0.05^{\mathrm{a}}$ & $3.5 I \pm 0.2 I^{a}$ & $1.10 \pm 0.09^{a}$ & $0.53 \pm 0.09^{a}$ & $0.79 \pm 0.02^{\mathrm{a}}$ \\
\hline 60 & 1.82 & $I . I I \pm 0.04^{a}$ & $3.48 \pm 0.34^{a}$ & $1.10 \pm 0.15^{a}$ & $0.53 \pm 0.03^{\mathrm{a}}$ & $0.78 \pm 0.04^{a}$ \\
\hline 60 & 2.32 & $1.17 \pm 0.03^{a}$ & $3.53 \pm 0.29^{a}$ & $1.13 \pm 0.18^{a}$ & $0.52 \pm 0.05^{\mathrm{a}}$ & $0.78 \pm 0.0 \mathrm{I}^{\mathrm{a}}$ \\
\hline 65 & $\mathrm{I} .37$ & $1.17 \pm 0.05^{b}$ & $3.49 \pm 0.32^{\mathrm{a}}$ & $1.21 \pm 0.19^{b}$ & $0.52 \pm 0.05^{\mathrm{a}}$ & $0.76 \pm 0.04^{b}$ \\
\hline 65 & 1.82 & $1.22 \pm 0.03^{b}$ & $3.52 \pm 0.35^{\mathrm{a}}$ & $1.23 \pm 0.14^{b}$ & $0.52 \pm 0.06^{\mathrm{a}}$ & $0.76 \pm 0.02^{b}$ \\
\hline 65 & 2.32 & $1.22 \pm 0.06^{b}$ & $3.50 \pm 0.29^{a}$ & $1.20 \pm 0.07^{\mathrm{b}}$ & $0.52 \pm 0.05^{\mathrm{a}}$ & $0.76 \pm 0.05^{b}$ \\
\hline 70 & 1.37 & $1.28 \pm 0.05^{c}$ & $3.49 \pm 0.16^{\mathrm{a}}$ & $1.35 \pm 0.12^{c}$ & $0.52 \pm 0.0 \mathrm{I}^{\mathrm{a}}$ & $0.76 \pm 0.03^{b}$ \\
\hline 70 & 1.82 & I. $37 \pm 0.07^{c}$ & $3.52 \pm 0.39^{\mathrm{a}}$ & $1.34 \pm 0.13^{c}$ & $0.52 \pm 0.0 \mathrm{I}^{\mathrm{a}}$ & $0.76 \pm 0.0 \mathrm{I}^{\mathrm{b}}$ \\
\hline 70 & 2.32 & $1.37 \pm 0.06^{c}$ & $3.47 \pm 0.36^{a}$ & $1.36 \pm 0.1 \mathrm{I}^{\mathrm{c}}$ & $0.52 \pm 0.03^{\mathrm{a}}$ & $0.75 \pm 0.04^{b}$ \\
\hline
\end{tabular}

Effect of temperature and air velocity on proximate composition of fermented corn grains

The influence of temperature and air velocity is clearly demonstrated on the proximate composition of the samples. The values ranged from $10.05-11.36 \%$ and exhibited significant difference at $\mathrm{p}<0.05$ through every temperature regime. The values of the moisture content were close to the values reported by Sule et al..$^{36}$ Temperature and air velocity did affect the moisture content in an inverse relationship because increase in air temperature and velocity decreased the moisture content proportionally. The lower values of moisture content recorded proved the stability of the corn flour during storage as water activity that could induce molds was reduced. Protein content of the corn grains ranged from 8.30 to $8.70 \%$ and the samples did exhibit significant difference as temperature changed but the change in the values did not follow any regular pattern; therefore it was difficult to study the influence of temperature and air velocity on the protein composition of the samples. The values of protein recorded were in close range with the values reported by Ujabadenyi \& Adebolu ${ }^{37}$ Fat content ranged from 3.23 to $3.56 \%$ and were significantly affected by temperatures and velocities as there were significant differences at $p<0.05$ in their values at different temperatures and velocities. Increase in temperature and air velocity decreased the fat content. This is because fat globules evaporated during mass transfer at higher temperatures compared to lower temperatures. The values were similar to those reported by Ikya et al., ${ }^{38}$ with value of $4.85 \%$. The values of ash content ranged from $1.25-1.33 \%$ without exhibiting significant difference among the samples at $\mathrm{p}<0.05$. The values were similar to those reported by Marina et al. ${ }^{39}$ The values of fibre content ranged from 2.10 to $2.13 \%$ and exhibited no significant difference at $\mathrm{p}<0.05$. The values were close to the values reported by Sule et al. ${ }^{36}$ The values of carbohydrate ranged from 74.23 to $74.53 \%$ and there was no significant difference among the samples. The values were comparable with those reported by Sule et al. ${ }^{36}$ In nutshell, the effect of temperatures and air velocities were not obvious on ash, fibre and carbohydrate content but were on moisture and fat content Table 9.

Effect of temperature and air velocity on physicochemical properties of fermented corn grains

The values of physico-chemical properties of fermented corn grains were as observed in Table 10. The water absorption capacity 
values ranged from 1.03 to $1.37 \mathrm{~cm}^{3} / \mathrm{g}$ and had significant difference at $\mathrm{p}<0.05$. The values were greater than the values reported by Adegunwa et al., ${ }^{40}$ with values range of 0.26 to $0.66 \mathrm{~cm}^{3} / \mathrm{g}$. The changes in values were obviously affected by temperature and air velocity as increase in temperature from 60 to $70^{\circ} \mathrm{C}$ increased water absorption from 1.03 to $1.37 \mathrm{~cm}^{3} / \mathrm{g}$. The reason for this is that water absorption capacity is moisture dependent, the higher the moisture content, the less the water absorption capacity. Also, water absorption capacity could be influenced by protein and fat interaction in the food samples. ${ }^{11}$ The values of least gelation capacity of the sample ranged from 3.47 to $3.53 \%$ and were not significantly different at $p<0.05$ as the influence of drying temperatures and velocities were not pronounced on these values. The values were in agreement with the values reported by Muhammad et al. ${ }^{41}$ Swelling capacity of the fermented corn grains ranged from 1.10 to $1.36 \mathrm{~g}$ water/g sample, the samples exhibited significant difference among one another at $p<0.05$. It was observed that as the temperature and air velocity increased, swelling capacity also increased. This could be as a result of low moisture content of samples at higher temperature as Tilahun ${ }^{42}$ related swelling capacity of flour to hydrogen bonds of water molecules in the starch structure. The values reported in this study were close to those reported by Sidibe \& Ajala et al., ${ }^{11,43}$ Swelling capacity of flour is useful to determine quality property of the flour because the higher the swelling capacity, the greater its usefulness in product formulation. ${ }^{11}$ The values of loose bulk density ranged from 0.52 to $0.53 \mathrm{~g} / \mathrm{cm}^{3}$. The drying parameters of temperature and air velocity had no effect on these values as there were no significant differences $(p<0.05)$ exhibited among the samples. Loose bulk density is a function of particle size distribution and is a primary measurement index for determining the quality of incoming raw materials. The values of packed bulk density ranged from 0.75 to $0.79 \mathrm{~g} / \mathrm{cm}^{3}$ and all samples dried at $60^{\circ} \mathrm{C}$ were significantly different from samples dried at 65 and $70^{\circ} \mathrm{C}$. The values of bulk density in this study were close to those values reported by Adegunwa et al..$^{40}$ The values of the samples reduced as the drying temperature increased. This could be as a result of lower moisture content of the samples at higher temperature of drying. Bulk density is useful in quality control, food packaging control, separation processes designing of packaging and transportation. ${ }^{11}$

\section{Conclusion}

Fick's law of diffusion for thin layer drying can be used to model drying characteristics of fermented corn; effective moisture diffusivity fall with the range of food products and increased with increase in temperature and velocity. Increase in temperature and velocity increased the values of water absorption and swelling capacity. On the contrary, moisture and fat content decreased with increase in temperature and velocity. ${ }^{44,45}$

\section{Acknowledgment}

Author declares no acknowledgment.

\section{Conflict of interest}

Author declares no conflict of interest.

\section{References}

1. FAO-STAT. Food and Agriculture Organization of the United Nations. Report on cassava production in the world. 2012.
2. Ajala AS, Ajala FA, Tunde Akintunde TY. Study on drying kinetics of fermented corn grains. Food Science and Quality Management. 2012;5:10-19.

3. Doebly JF. Morphology, molecules and maize corn and culture in the prehistoric new world. Geneva, Switzerland, $4^{\text {th }}$ ed. 1994. p. 65-69

4. Jadhav AS, Naniwadekar MY, Shila R. Enzymatic hydrolysis of maize for synthesis of ethanol. International Journal of Chemical and Petrochemical Technology (IJCPT). 2013;3(4):7-14.

5. Osugbaro. Effect of differences in varieties and dry milling of maize and textural characteristics of ogi (fermented maize porridge) and 'agidi' (fermented maize meal). Journal of Science, Food and Agriculture. 1990;52(1):1-12.

6. Osugbaro TO. Physical and nutritive properties of fermented cereal foods. African Journal of Food Science. 2009;32(2):23-27.

7. Akobundu and Hoskins. Protein losses in traditional 'agidi' paste. Journal of Food Science.1982;47(5):1728-1729.

8. Onuk EG, Ogara IM, Yahaya H, et al. Economic evaluation of maize production in Mangu Local Government Area of Plateau State, Nigeria. 2010;6(11)1-11.

9. Jain D, Pathare PB. Study the drying kinetics of open sun drying of fish Journal of Food Engineering. 2007;78(4):1315-1319.

10. Thuwapanichayanan R, Prachayawarakorn S, Soponronnarit S. Drying characteristics and quality of banana foam mat. Journal of Food Engineering. 2008;86(4):573-583.

11. Ajala AS, Aboiye AO, Popoola JO, et al. Drying characteristics and mathematical modelling of cassava chips. Chemical and Process Engineering Research. 2012;4:1-9.

12. Goyal RK, Kingsley ARP, Manikantan MR, et al. Mathematical modeling of thin layer drying kinetics of plum in a tunnel dryer. Journal of Food Engineering. 2007;79(1):176-180.

13. Ajala AS, Ajala FA. A study on drying kinetics of shrimps. International Journal of Innovation and Applied Studies. 2014;9(4):1778-1785.

14. Demir V, Gunhan T, Yagcioglu AK, et al. Mathematical modeling and the determination of some quality parameters of air dried bay leaves. Biosystems Engineering. 2004;88(3):429-437.

15. Srikiatden J, Roberts JS. Moisture loss kinetics of apple during convective hot air and isothermal drying. International Journal of Food Propertie. 2005;8(3):493-512.

16. Aregbesola OA, Ogunsina BS, Sofolahan AE, et al. Mathematical modeling of thin layer drying characteristics of 'dika'(Irvingia gabonensis) nuts and kernels. Nigerian Food Journal. 2015;33(1):83-89.

17. Kingly RP, Goyal RK, Manikantan MR, et al. Effect of pretreatment and drying air temperature on drying behaviour of peach slice. International Journal of Food Science and Technology. 2007;42(1):65-69.

18. Midilli A, Kucuk H, Yapar Z. A new model for single layer drying. Drying Technology. 2002;20(7):1503-1513.

19. Togrul IT, Pehlivan D. Modelling of drying kinetics of single apricot. Journal of Food Engineering. 2003;58(1):23-32.

20. Doymaz I. Convective air drying characteristics of thin layer carrots. Journal of Food Engineering. 2004;61(3):359-364.

21. AOAC. Official Methods of Analysis. 16th ed. Virginia, USA; 2005. p. 834-841.

22. Ajala AS. Optimization of the drying of cassava chips in a tunnel dryer. Ladoke Akintola University of Technology, Ogbomoso, Nigeria; 2014. 
23. Velić D, Bilić M, Tomas S, et al. Study of the drying kinetics of "Granny Smith" apple in tray drier. Agriculture Conspectus of Science. 2007;72(4):326-332.

24. Karel M, Lund DB. Physical Principles of Food Preservation. New York, Marcel; 2003.

25. Ramaswamy H, Marcotte M. Food Processing-Principles and Applications. London: Taylor and Francis Group; 2006.

26. Bellagha S, Amami E, Fahart H, et al. Drying kinetics and characteristics drying curve of lightly salted sardine. Proceeding of the $13^{\text {th }}$ international drying symposium. 2002;20(7):1583.

27. Guine R, Lopes P, Joao BM, et al. Effect of ripening stage on drying kinetics and properties of S. Bartolomeu pears. International Journal of Academic Research. 2009;1(1):3.

28. Belghit A, Kouhila M, Boutaleb BC. Experimental study of drying kinetics of sage in a tunnel working in forced convection. Review Energy. 1999;2:17-26.

29. ASTM. Standard temperature for measuring humidity with a psycrometer: the measurement of wet \& dry bulb temperature. American Society for Testing and Materials, International, West Conshohocken; 2005. p. 1226 1249.

30. Abraham DG, Arolilo AP, Rosimeire MR, et al. The air drying behaviour of osmotically dehydrated jackfruit. Proceeding $14^{\text {th }}$ International Drying Symposium. 2004;1:1-3.

31. Hawlander MNA, Uddin MS, Ho JC, et al. Drying characteristics of tomatoes. Journal of Food Engineering. 1991;14(4):249-268.

32. Welti J, Palou E, Lopez Malo E, et al. Osmotic concentration- drying of mango slices. Drying Technology. 1995;1(2):405-416.

33. Jaya S, Das H. A vacuum drying model for mango pulp. Drying Technology. 2003;21(7):1215-1221.

34. Doymaz I. Air drying characteristics of tomatoes. Journal of Food Engineering. 2007;78(4):1291-1297.

35. Akanbi CT, Adeyemi RS, Ojo A. Drying characteristics and sorption isotherm of tomato slices. Journal of Food Engineering. 2006;73(2):141146.
36. Sule EI, Umoh VJ, Whong CMZ, et al. Chemical and nutritional value of maize and maize products obtained from selected markets in Kaduna State, Nigeria. African Journal of Food Science and Technology. 2014;5(4):100-104

37. Ujabadeniyi AO, Adebolu JT. The effect of processing method on nutritional properties of ogi produced from three maize varieties. Journal of Food, Agriculture and Environment. 2005;3:108-109.

38. Ikya JK, Gernah DI, Sengev IA. Proximate composition, nutritive and sensory properties of fermented maize, and full fat soy flour blends for “agidi” production. 2013;7(12):446-450.

39. Marina CN Assohoun, Théodore ND, Marina KC, et al. Effect of fermentation process on nutritional composition and aflatoxins concentration of 'doklu', fermented maize based food. Food and Nutrition Sciences. 2013;4:1120-1127.

40. Adegunwa MO, Alamu EO, Bakare HA, et al. Effect of fermentation length and varieties on the qualities of corn starch (Ogi) production. American Journal of Food and Nutrition. 2011;1(4):166-170.

41. Muhammad AS, Haq N, Misbah N, et al. Functional properties of maize flour and its blends with wheat flour: optimization of preparation conditions by response surface methodology. Pakistan Journal of Botany. 2013;45(6):2027-2035.

42. Tilahun A. Effect of processing on some physicochemical composition and anti-nutritional factors of locally grown cassava varieties. An MSc thesis in Food Science and Nutrition Department, Addis Ababa University; 2009. p. 60-67.

43. Sidibe D, Sako A, Dally L, et al. Thermal effect on granules and direct determination of swelling capacity of starch from a cassava cultivar (Attieke Mossi) cultivated in Cote D'Ivore. African Journal of Biotechnology. 2009;15:3615-3622.

44. Chinnman. Evaluation of selected mathematical models for describing thin layer drying of in-shell pecans. 1984;27(2):610-615

45. Foods. African Journal of Food Science. 3(2):23-27. 